\title{
Influence of Health Beliefs on Adherence to COVID-19 Preventative Practices: International, Social Media-Based Survey Study
}

Julianna C Hsing ${ }^{1,2}$, BA; Jasmin $\mathrm{Ma}^{2}$, BS; Alejandra Barrero-Castillero ${ }^{3,4,5}$, MD, MPH; Shilpa G Jani², MPH; Uma Palam Pulendran ${ }^{2}$, MPH; Bea-Jane Lin ${ }^{2}$, PhD; Monika Thomas-Uribe ${ }^{6}$, MD, MPH; C Jason Wang ${ }^{2,7,8}$, MD, PhD

${ }^{1}$ Department of Epidemiology and Population Health, Stanford University School of Medicine, Stanford, CA, United States

${ }^{2}$ Center for Policy, Outcomes, and Prevention, Department of Pediatrics, Stanford University School of Medicine, Stanford, CA, United States

${ }^{3}$ Division of Neonatology, Beth Israel Deaconess Medical Center, Boston, MA, United States

${ }^{4}$ Division of Newborn Medicine, Boston Children's Hospital, Boston, MA, United States

${ }^{5}$ Department of Pediatrics, Harvard Medical School, Boston, MA, United States

${ }^{6}$ Department of Pediatrics, University of California San Francisco - Fresno, Fresno, CA, United States

${ }^{7}$ Center for Health Policy, Freeman-Spogli Institute for International Studies, Stanford University, Stanford, CA, United States

${ }^{8}$ Center for Primary Care Outcomes Research, Stanford University School of Medicine, Stanford, CA, United States

\section{Corresponding Author:}

C Jason Wang, MD, PhD

Center for Policy, Outcomes, and Prevention

Department of Pediatrics

Stanford University School of Medicine

117 Encina Commons, CHP/PCOR

Stanford, CA, 94305

United States

Phone: 1 (650) 7360403

Email: cjwang1@stanford.edu

\section{Abstract}

Background: Health behavior is influenced by culture and social context. However, there are limited data evaluating the scope of these influences on COVID-19 response.

Objective: This study aimed to compare handwashing and social distancing practices in different countries and evaluate practice predictors using the health belief model (HBM).

Methods: From April 11 to May 1, 2020, we conducted an online, cross-sectional survey disseminated internationally via social media. Participants were adults aged 18 years or older from four different countries: the United States, Mexico, Hong Kong (China), and Taiwan. Primary outcomes were self-reported handwashing and social distancing practices during COVID-19. Predictors included constructs of the HBM: perceived susceptibility, perceived severity, perceived benefits, perceived barriers, self-efficacy, and cues to action. Associations of these constructs with behavioral outcomes were assessed by multivariable logistic regression.

Results: We analyzed a total of 71,851 participants, with 3070 from the United States, 3946 from Mexico, 1201 from Hong Kong (China), and 63,634 from Taiwan. Of these countries, respondents from the United States adhered to the most social distancing practices $\left(\chi_{3}^{2}=2169.7, P<.001\right)$, while respondents from Taiwan performed the most handwashing $\left(\chi_{3}^{2}=309.8, P<.001\right)$. Multivariable logistic regression analyses indicated that self-efficacy was a positive predictor for handwashing (odds ratio $[\mathrm{OR}]_{\text {United States }} 1.58,95 \%$ CI 1.21-2.07; OR Mexico $_{1.5,95 \% \text { CI 1.21-1.96; OR }}$ Hong Kong $2.48,95 \%$ CI 1.80-3.44; OR ${ }_{\text {Taiwan }} 2.30,95 \%$ CI 2.21-2.39) and social distancing practices $\left(\mathrm{OR}_{\text {United States }} 1.77,95 \%\right.$ CI 1.24-2.49; $\mathrm{OR}_{\text {Mexico }} 1.77,95 \%$ CI 1.40-2.25; OR $\mathrm{Hong}$ Kong $3.25,95 \%$ CI 2.32-4.62; OR $\mathrm{OR}_{\text {Taiwan }} 2.58$, 95\% CI 2.47-2.68) in all countries. Handwashing was positively associated with perceived susceptibility in Mexico, Hong Kong, and Taiwan, while social distancing was positively associated with perceived severity in the United States, Mexico, and Taiwan. 
Conclusions: Social media recruitment strategies can be used to reach a large audience during a pandemic. Self-efficacy was the strongest predictor for handwashing and social distancing. Policies that address relevant health beliefs can facilitate adoption of necessary actions for preventing COVID-19. Our findings may be explained by the timing of government policies, the number of cases reported in each country, individual beliefs, and cultural context.

(J Med Internet Res 2021;23(2):e23720) doi: 10.2196/23720

\section{KEYWORDS}

COVID-19 pandemic; health belief model; behavior change; preventative health behaviors; handwashing; social distancing; international; online survey; social media; cross-sectional study

\section{Introduction}

The severity and rapid transmission of COVID-19 has forced most regions to implement community mitigation strategies. These strategies have ranged from government guidelines on personal protective measures and social distancing to strict lockdown orders that closed schools and businesses [1]. Nationwide school closures in 194 countries in early April 2020 demonstrated the extent of these interventions [2]. These measures have reduced transmission or delayed the peak of infection of past pandemics to varying degrees, which were estimated to have prevented at least 60 million COVID-19 cases $[3,4]$.

Although these interventions reduce the stress on health care systems, they also incur high economic and societal costs, making adherence more difficult for those under financial strain $[3,5]$. Recent studies have begun to assess adherence to COVID-19 guidelines, evaluating demographic characteristics and the impact of guideline duration [6-8]. Some have suggested that concepts from social and behavioral sciences can provide insight into adherence to guidelines, but current data evaluating these hypotheses in multiple countries and in the context of COVID-19 using relevant behavior change theories, such as the health belief model (HBM), are limited [9]. Given the rapid spread of COVID-19 and the scale of guidelines worldwide, a cross-cultural assessment of preventative health behaviors is essential to identifying which approaches improve adherence. This study aims to compare handwashing and social distancing behaviors across four different countries using the HBM.

\section{Methods}

\section{Participant Recruitment}

From April 11 to May 1, 2020, we conducted a confidential, cross-sectional, international open survey through the following social media platforms: Facebook, Instagram, Line, and Twitter. The survey was announced and advertised through Stanford Health Policy's social media accounts. Facebook boosted posts were used to target social media users who were 18 years of age or older. We focused our analysis on countries and regions with at least 1000 survey responses: the United States, Mexico,
Hong Kong (China), and Taiwan. Facebook is the most popular social media platform among adults in all four countries, whereas Instagram, Twitter, and Line have relatively high penetration in specific groups and countries [10-13]. Though the limitations of using convenience sampling and social media are well-known, this method is cost-effective, time-efficient, and most feasible for reaching a large international audience in a fast-spreading pandemic [14]. The alternative of administering telephone surveys is associated with extremely low response rates (6\% in 2018) and limitations on item complexity and survey length $[15,16]$.

The survey was developed on Qualtrics (Qualtrics Inc), an online survey distribution tool, and administered in English, Spanish, and Mandarin. Translations were provided by native speakers fluent in the respective languages, who tested the survey before it was fielded. Prior to survey completion, participants were provided with information about the study and were asked to acknowledge consent to the study. All items were optional except for country of residence. Through Qualtrics, cookies were used to assign a unique user identifier to each client computer to prevent participants from completing the survey more than once. Only completed surveys were analyzed. Given that no incentives were offered to participants and that the survey was voluntary, we did not assess whether surveys were completed in an atypical amount of time. The study was reviewed and approved by Stanford University's Institutional Review Board.

\section{Conceptual Model and Survey Items}

We used the HBM, a widely used framework for explaining health behaviors and guiding related interventions, to create survey items to assess health beliefs among respondents in the four countries [17]. The HBM accounts for both individual- and community-level factors of health motivation, making it an ideal option for addressing health behavior problems that evoke health concerns during the COVID-19 pandemic. Figure 1 shows the key constructs in the HBM that determine behavior, including individual beliefs (ie, perceived susceptibility, severity, benefits, and barriers as well as self-efficacy), which may be influenced by sociodemographic factors or knowledge, and cues to action, which may be influenced by public policy. 
Figure 1. Conceptual framework of the study adapted from the health belief model to assess individual health beliefs, modifying factors, and the effects of public policy on social distancing and handwashing behaviors during the COVID-19 pandemic. CDC: Centers for Disease Control and Prevention; WHO: World Health Organization.

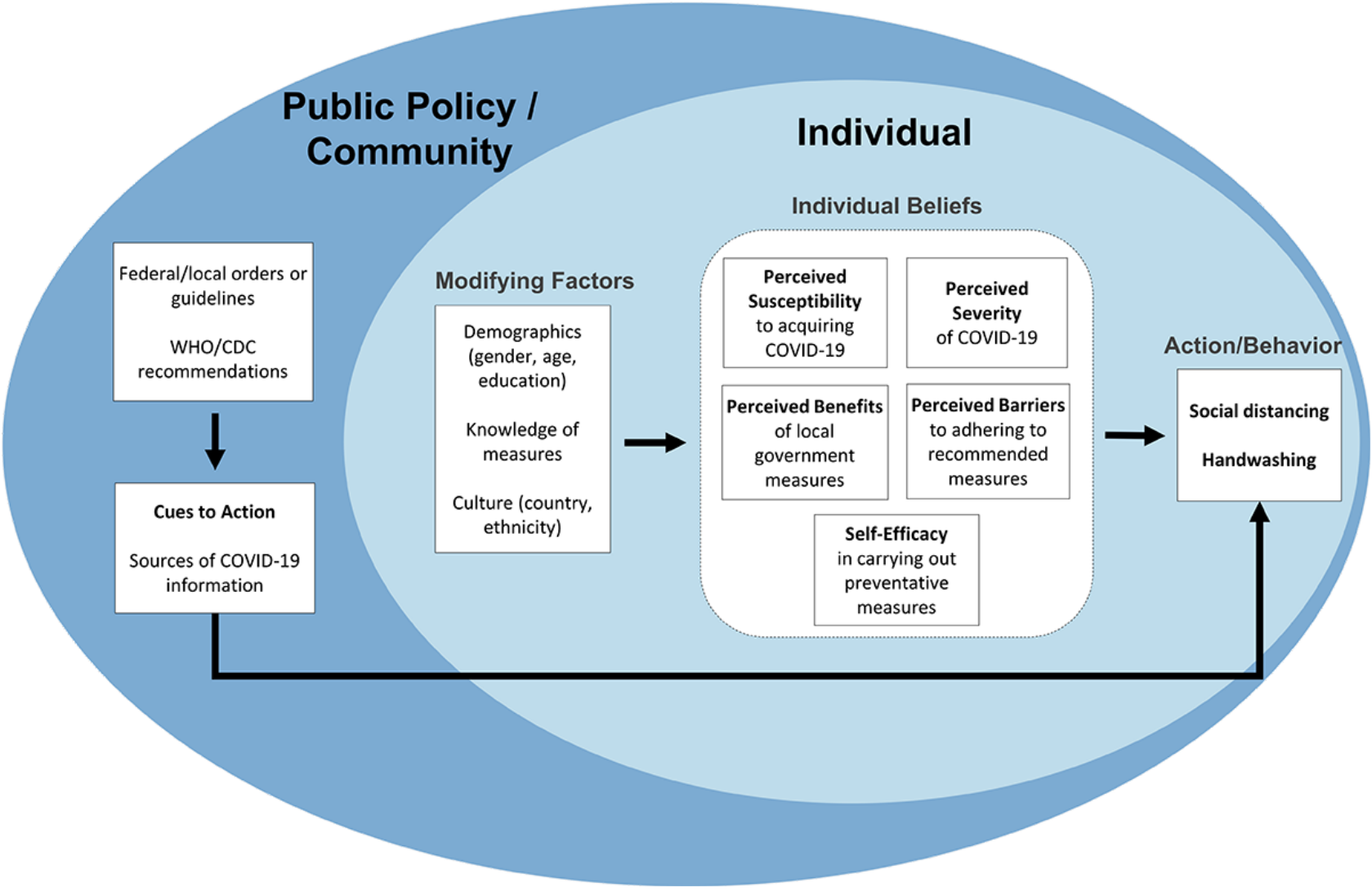

Survey items (see Multimedia Appendix 1) were developed based on prior expertise, survey knowledge, and group discussion. We asked participants the following questions for each HBM construct:

1. Perceived susceptibility. What do you think your risk is of getting infected with COVID-19?

2. Perceived severity. How afraid are you of the COVID-19 pandemic?

3. Perceived benefits. How do you feel about the government measures of COVID-19 in your area?

4. Perceived barriers. Have any barriers prevented you from adhering to measures in your area?

5. Self-efficacy. How confident are you that you are able to and willing to carry out these measures?

6. Cues to action. What are your sources of information regarding COVID-19?

Perceived susceptibility, perceived severity, and self-efficacy items were assessed using a 5-point Likert scale. During analysis, response scales were eventually collapsed into three categories, such as not likely/slightly likely, moderately likely, and likely/very likely. Perceived benefit items were assessed using three categories: unnecessarily restrictive/moderately restrictive, essential/appropriate, and not enough. Perceived barriers and cues to action were both assessed on a binary yes/no scale.

To account for modifying factors that influenced individual beliefs, we assessed for age (ie, 18-24, 25-34, 35-44, 45-59, and $60+$ years), gender (ie, male, female, and other), highest educational attainment (ie, high school or less and college and above), country of residence (ie, United States, Mexico, Hong Kong, and Taiwan), race or ethnicity (eg, Asian, Hispanic/Latino, and White or European), change in income due to COVID-19 (ie, yes or no), and awareness of government measures or guidelines (ie, some/not aware and most/all).

Handwashing behaviors were assessed by asking respondents whether they washed their hands or used hand sanitizer in the following seven situations: (1) after coming home from being outside; (2) after grocery shopping; (3) after interacting with nonhousehold members; (4) while being in public; (5) before or after using their vehicle; (6) after blowing their nose, coughing, or sneezing into their hand; and (7) before eating. Responses for all situations were summed up to a score of 7 . Social distancing behaviors were evaluated by assessing whether respondents did the following: (1) avoided nonessential gatherings, (2) kept at least the recommended distance from nonhousehold members (eg, 6 feet, 1.5 meters, 2 meters, etc), or (3) avoided close contact with individuals at higher risk for severe illness from COVID-19. Responses were summed up to a score of 3. Total adherence to either handwashing or social distancing responses was assessed by a binary variable, with individuals performing all of the practices as one group (yes = 1) and those who performed fewer than all practices as the other group (no $=0$ ); this was done for each of the two behaviors.

\section{Statistical Analysis}

We conducted poststratification weighting for each country by age and gender-and race or ethnicity for the United 
States-using each country's most recent census data [18-21]. Weights were calculated by dividing each stratified proportion of the country's population by each stratified proportion of the study's country sample, followed by renormalizing for each country to ensure that weighted sample size equaled the unweighted sample size [22]. Weighted frequencies and percentages were calculated for categorical variables and compared using chi-square tests. To assess which country performed more handwashing and social distancing practices, countries were analyzed together in multivariate analyses, with each country coded as a key independent dichotomous variable, adjusting for gender, age, education, and reduced income.

Countries were also analyzed separately with multivariable logistic regressions to examine the association of HBM constructs with two main outcomes: handwashing and social distancing practices. HBM covariates included perceived susceptibility, severity, benefits, and barriers; self-efficacy; and cues to action. All models were adjusted for gender, age, education, and reduced income. To ensure our handwashing variable appropriately captured COVID-19-related handwashing behaviors, we also ran a sensitivity analysis that assessed the association between handwashing time (ie, >20 seconds vs $\leq 20$ seconds) and HBM constructs, because this handwashing duration was a specific COVID-19 recommendation in all four countries [23-26]. For all models, odds ratios (ORs) and 95\% CIs were calculated. All statistical analyses were performed using R statistical software, version 3.6.3 (The R Foundation), and $P$ values were 2 -sided with an $\alpha$ of .05 .

\section{Results}

\section{Participant Characteristics}

A total of 71,851 individuals were included in our analysis: 3070 from the United States (4.3\%), 3946 from Mexico (5.5\%), 1201 from Hong Kong (1.7\%), and 63,634 from Taiwan $(88.6 \%)$. Of these, $71,728(99.8 \%)$ completed at least $80 \%$ of the survey (14 of 17 questions). Missing data for each item were less than 5\% and, thus, were not imputed. After weighting, the gender and age distributions were representative of each country according to their most recent census data (see Multimedia Appendices 2 and 3). Overall, Mexico had a younger population compared to other countries, and most respondents in all four countries had a college degree or higher. A total of 2099 out of 3931 respondents (53.4\%) from Mexico, 337 out of 1189 (28.3\%) from Hong Kong, 779 out of 3062 (25.4\%) from the United States, and 10,725 out of 63,399 (16.9\%) from Taiwan reported reduced income due to COVID-19. A total of 68,614 out of 71,633 respondents $(95.8 \%)$ in all countries were aware of government measures and/or guidelines (see Table 1). 
Table 1. Weighted demographic characteristics of survey respondents by country.

\begin{tabular}{|c|c|c|c|c|c|}
\hline \multirow[t]{2}{*}{ Characteristic } & \multicolumn{4}{|l|}{ Value $(\mathrm{N}=71,851), \mathrm{n}(\%)^{\mathrm{a}}$} & \multirow[t]{2}{*}{$P$ value $^{\mathrm{b}}$} \\
\hline & United States $(\mathrm{n}=3070)$ & Mexico (n=3946) & Hong Kong $(n=1201)$ & Taiwan $(\mathrm{n}=63,634)$ & \\
\hline Age group (years) & & & & & $<.001$ \\
\hline $18-24$ & $110(3.6)$ & $507(12.9)$ & $83(7.0)$ & $4969(7.8)$ & $-^{\mathrm{c}}$ \\
\hline $25-34$ & $519(17.0)$ & $953(24.2)$ & $198(16.6)$ & $10,509(16.6)$ & - \\
\hline $35-44$ & $451(14.7)$ & $820(20.8)$ & $226(18.9)$ & $12,865(20.3)$ & - \\
\hline $45-59$ & $963(31.4)$ & $977(24.8)$ & $310(25.9)$ & $17,836(28.1)$ & - \\
\hline $60+$ & $1019(33.3)$ & $684(17.3)$ & $377(31.6)$ & $17,294(27.2)$ & - \\
\hline Gender & & & & & $<.001$ \\
\hline Female & $1683(55.0)$ & $2031(51.6)$ & $602(50.4)$ & 31,407 (49.6) & - \\
\hline Male & $1351(44.2)$ & $1867(47.4)$ & $562(47.1)$ & $30,034(47.4)$ & - \\
\hline Other $^{d}$ & $25(0.8)$ & $40(1.0)$ & $30(2.5)$ & $1894(3.0)$ & - \\
\hline Race or ethnicity & & & & & $<.001$ \\
\hline Asian & $158(5.2)$ & $15(0.4)$ & $1180(98.9)$ & $62,924(99.3)$ & - \\
\hline Hispanic/Latino or other ${ }^{\mathrm{e}}$ & $1520(49.7)$ & $3319(84.7)$ & $11(0.9)$ & $228(0.4)$ & - \\
\hline White or European & $1379(45.1)$ & $586(15.0)$ & $2(0.2)$ & $207(0.3)$ & - \\
\hline Education & & & & & $<.001$ \\
\hline Below college & $286(9.4)$ & $726(18.4)$ & $263(22.2)$ & $7889(12.4)$ & - \\
\hline College and above & 2768 (90.6) & $3215(81.6)$ & $923(77.8)$ & $55,547(87.6)$ & - \\
\hline Reduced income since COVID-19 & & & & & $<.001$ \\
\hline No & $2283(74.6)$ & $1832(46.6)$ & $852(71.7)$ & $52,674(83.1)$ & - \\
\hline Yes & $779(25.4)$ & $2099(53.4)$ & $337(28.3)$ & $10,725(16.9)$ & - \\
\hline $\begin{array}{l}\text { Awareness of governmental measures } \\
\text { and/or guidelines }\end{array}$ & & & & & $<.001$ \\
\hline Some/not aware & $20(0.7)$ & $123(3.1)$ & $26(2.2)$ & $2850(4.5)$ & - \\
\hline All/most & $3034(99.3)$ & $3818(96.9)$ & $1167(97.8)$ & $60,595(95.5)$ & - \\
\hline
\end{tabular}

${ }^{a}$ Weighted values were calculated by dividing the actual proportion of the country's population by the proportion from the study's sample, then renormalized for each country to ensure weighted and unweighted sample sizes were equal. Due to rounding and missing data $(<5 \%$ for each item), the sum of frequencies and percentages for the sample weighted columns may not equal the country's total sample size.

${ }^{\mathrm{b}} P$ values were calculated using 2 -sided chi-square tests.

${ }^{\mathrm{c}}$ Not available.

${ }^{\mathrm{d}}$ Responses of other gender include individuals who chose nonbinary/third gender, prefer not to say, or other (<3\% of total responses).

${ }^{\mathrm{e}}$ Responses of other race or ethnicity include individuals who are African, Black, African American, American Indian or Alaskan Native, Middle Eastern, Native Hawaiian or other Pacific Islander, or other. Categories were collapsed due to low numbers ( $<2 \%$ of total responses).

\section{Handwashing and Social Distancing Behaviors}

Bivariate chi-square analyses showed that respondents from Taiwan practiced the most handwashing behaviors $\left(\chi_{3}^{2}=309.8\right.$, $P<.001)$ relative to other countries, while those from the United States practiced the most social distancing $\left(\chi_{3}^{2}=2169.7, P<.001\right)$. Of the 71,608 respondents who provided a response to their handwashing practices, 39.6\% (1215/3066) from the United States, 48.8\% (1927/3938) from Mexico, 45\% (538/1195) from Hong Kong, and 54.1\% $(34,328 / 63,409)$ from Taiwan reported handwashing in all seven situations (see Figure 2). Of the 71,851 respondents who provided a response to their social distancing practices, 88.0\% (2702/3070) from the United States, 64.3\%
(2539/3946) from Mexico, 44.7\% (537/1201) from Hong Kong, and $48.3 \%(30,737 / 63,634)$ from Taiwan reported performing all three social distancing practices (see Figure 3). We found similar patterns of association in the sensitivity multivariate analysis (see Multimedia Appendix 4). Respondents from the United States (OR 0.50, 95\% CI 0.46-0.54), Mexico (OR 0.87, 95\% CI 0.81-0.93), and Hong Kong (OR 0.67, 95\% CI 0.59-0.75) were less likely to perform handwashing compared to those from Taiwan (reference value). Respondents from the United States (OR 7.73, 95\% CI 6.93-8.66) and Mexico (OR $2.17,95 \%$ CI 2.02-2.33) were more likely to practice social distancing compared to those from Taiwan. In contrast, respondents from Hong Kong were less likely to practice social 
distancing compared to those from Taiwan, although the 0.87-0.99). association was only slightly significant (OR $0.88,95 \% \mathrm{CI}$

Figure 2. Distribution of handwashing practices by country. Respondents were asked whether they washed their hands or used hand sanitizer in any of the following seven situations: (1) after coming home from being outside; (2) after grocery shopping; (3) after interacting with nonhousehold members; (4) while being in public; (5) before or after using their vehicle; (6) after blowing their nose, coughing, or sneezing into their hand; and (7) before eating.

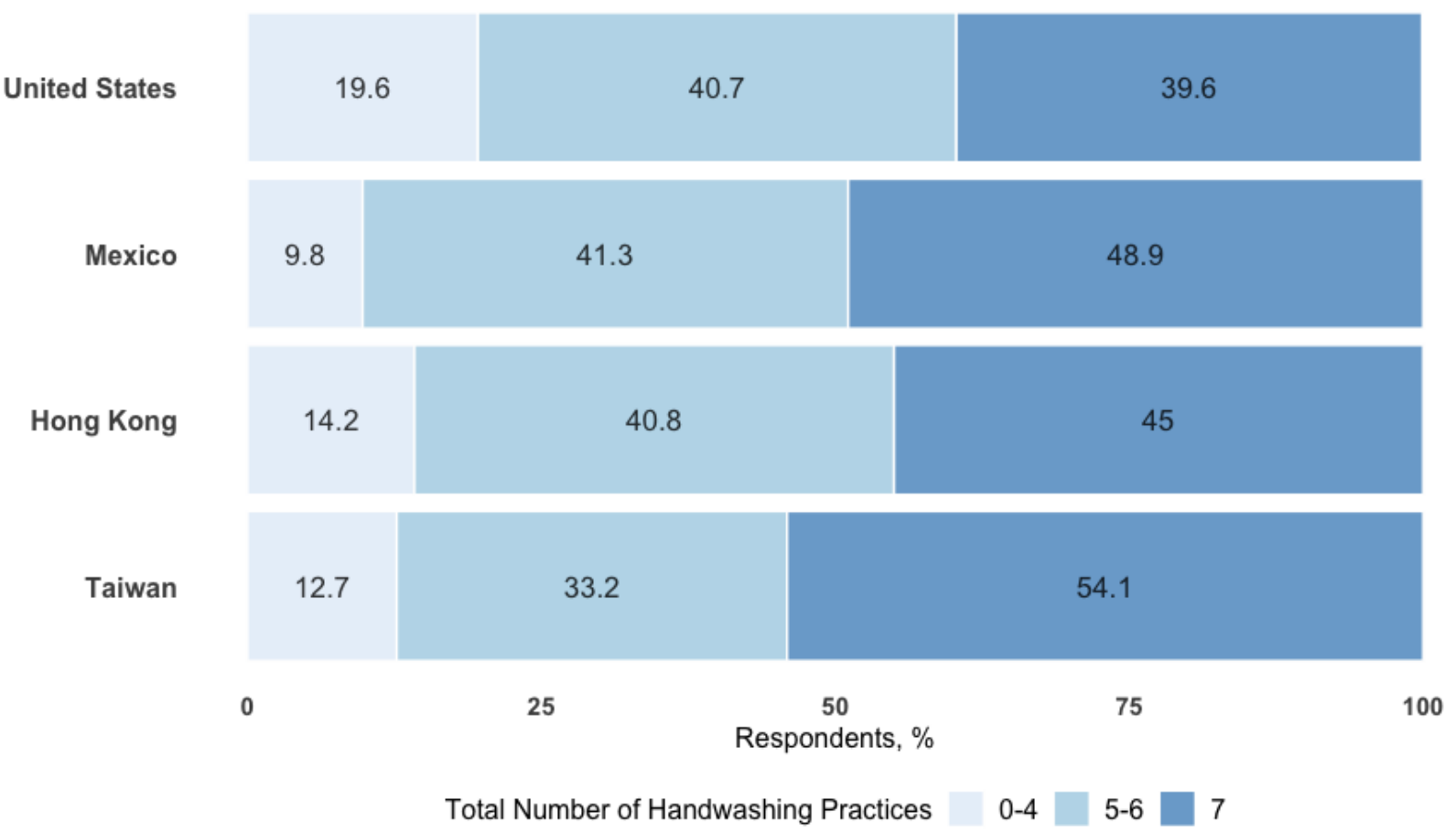

Figure 3. Distribution of social distancing practices by country. Respondents were asked whether they did the following: (1) avoided nonessential gatherings, (2) kept at least the recommended healthy distance from nonhousehold members (eg, 6 feet, 1.5 meters, and 2 meters), or (3) avoided close contact with individuals at higher risk for severe illness from COVID-19.

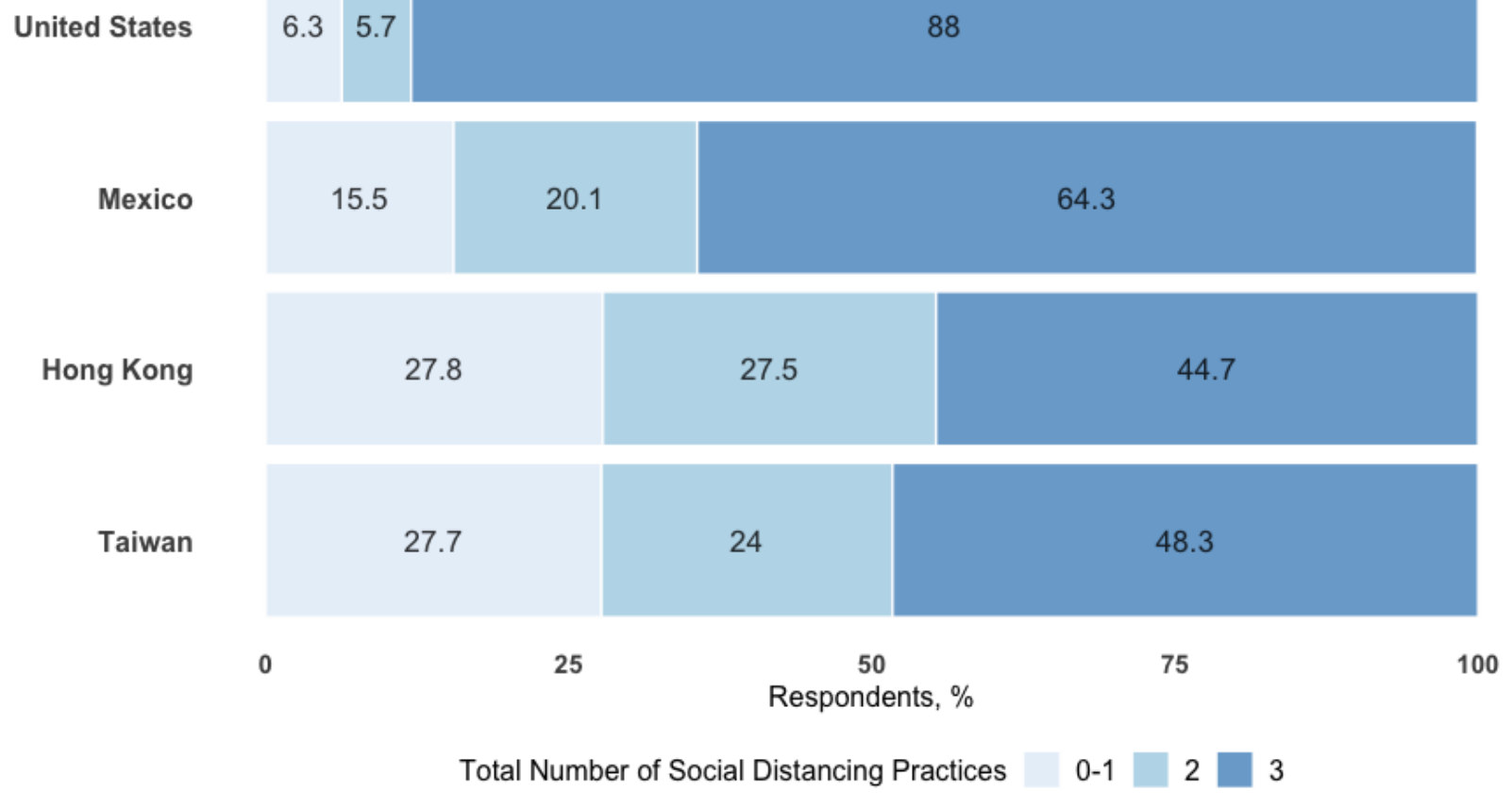




\section{Health Belief Model Constructs}

Table 2 compares the distribution of responses to health belief questions by country, which were assessed using chi-square tests and were all statistically different across each country $(P<.001)$. For perceived susceptibility, the percentage of respondents who felt they were likely (ie, moderately likely to very likely) to be infected with COVID-19 was higher in the United States (1683/3068, 54.9\%) and Mexico (2688/3941, $68.2 \%$ ) compared to those from Hong Kong (557/1192, 46.7\%) and Taiwan $(19,080 / 63,425,30.1 \%)$. For perceived severity, a higher percentage of individuals from Taiwan (28,082/63,470, $44.2 \%$ ) were not afraid (ie, slightly afraid or not afraid) of the COVID-19 pandemic compared to those from the United States (876/3064, 28.6\%), Mexico (1154/3940, 29.3\%), and Hong Kong $(289 / 1195,24.2 \%)$. For perceived benefits, most individuals in the United States $(2062 / 3016,68.4 \%)$ and Taiwan $(53,573 / 62,625,85.5 \%)$ believed that the government measures in place were appropriate or essential, while most individuals in Mexico (2256/3871, 58.3\%) and Hong Kong (745/1172, $63.6 \%$ ) believed that their measures were not enough. For self-efficacy, a majority of individuals in all countries were confident or very confident in their ability to carry out preventative measures: $88.5 \%$ (2712/3066) in the United States, 91.4\% (3599/3940) in Mexico, 79.3\% (946/1193) in Hong Kong, and $75.8 \%(48,144 / 63,481)$ in Taiwan.

Regarding perceived barriers to social distancing, Mexico $(2547 / 3946,64.5 \%)$ had the highest proportion of individuals who perceived difficulty in obtaining face masks, followed by $60.5 \%(1856 / 3070)$ of individuals in the United States, $52.7 \%$ $(633 / 1201)$ in Hong Kong, and $12.2 \%(7736 / 63,634)$ in Taiwan. Having an essential job (eg, grocery store worker), as perceived by the individual or determined by local governments, was a common perceived barrier in all countries. Other common barriers included family obligations in Mexico as well as transportation needs in Hong Kong and Taiwan. For handwashing barriers, respondents from the United States $(1536 / 3070,50.0 \%)$ and Mexico (2056/3946, 52.1\%) perceived more difficulty in obtaining hand sanitizer compared to those in Taiwan $(2708 / 63,634,4.3 \%)$ and Hong Kong (104/1201, $8.7 \%)$. Only a small proportion of individuals in all countries $(<5 \%$ each) reported having difficulty obtaining hand soap.

For cues to action, respondents selected up to three sources of information for COVID-19. News (eg, TV news, newspaper, and radio) and social media were the most frequently reported sources of information in every country, with Hong Kong reporting the highest percentage (news: 1002/1201, 83.4\%; social media: $846 / 1201,70.4 \%$ ) and Mexico the lowest (news: 1965/3946, 49.8\%; social media: 1337/3946, 33.9\%). More respondents selected federal, or central, government rather than regional government as a top information source in Taiwan $(14,730 / 63,634,23.1 \%$ vs $1387 / 63,634,2.2 \%)$ and Mexico $(1155 / 3946,29.3 \%$ vs 567/3946, 14.4\%), while more respondents selected regional rather than federal government in the United States (1129/3070, 36.8\% vs 312/3070, 10.2\%). Both choices were comparably low in Hong Kong ( $<5 \%$ each). 
Table 2. Weighted responses to health belief model (HBM) constructs by country.

\begin{tabular}{|c|c|c|c|c|c|}
\hline \multirow[t]{2}{*}{ HBM construct, survey question, and responses } & \multicolumn{4}{|c|}{ Value $(\mathrm{N}=71,851), \mathrm{n}(\%)^{\mathrm{a}}$} & \multirow[t]{2}{*}{$P$ value $^{\mathrm{b}}$} \\
\hline & $\begin{array}{l}\text { United States } \\
(\mathrm{n}=3070)\end{array}$ & $\begin{array}{l}\text { Mexico } \\
(\mathrm{n}=3946)\end{array}$ & $\begin{array}{l}\text { Hong Kong } \\
(\mathrm{n}=1201)\end{array}$ & $\begin{array}{l}\text { Taiwan } \\
(\mathrm{n}=63,634)\end{array}$ & \\
\hline $\begin{array}{l}\text { Perceived susceptibility to infection: What do you think is } \\
\text { your risk of getting infected with COVID-19? }\end{array}$ & & & & & $<.001$ \\
\hline Not likely/slightly likely & $1385(45.1)$ & $1253(31.8)$ & $635(53.3)$ & $44,345(69.9)$ & $-\mathrm{c}$ \\
\hline Moderately likely & $1024(33.4)$ & $1523(38.6)$ & $331(27.7)$ & $10,038(15.8)$ & - \\
\hline Likely/very likely & $659(21.5)$ & 1165 (29.6) & $226(19.0)$ & $9042(14.3)$ & - \\
\hline $\begin{array}{l}\text { Perceived severity of COVID-19: How afraid are you of the } \\
\text { COVID-19 pandemic? }\end{array}$ & & & & & $<.001$ \\
\hline Not afraid/slightly afraid & $876(28.6)$ & $1154(29.3)$ & $289(24.2)$ & $28,082(44.2)$ & - \\
\hline Moderately afraid & $1022(33.3)$ & $1135(28.8)$ & $374(31.3)$ & $15,216(24.0)$ & - \\
\hline Afraid/very afraid & $1166(38.1)$ & $1651(41.9)$ & $532(44.5)$ & $20,172(31.8)$ & - \\
\hline $\begin{array}{l}\text { Perceived benefits of measures: How do you feel about the } \\
\text { government measures for COVID-19 in your area? }\end{array}$ & & & & & $<.001$ \\
\hline Appropriate/essential & $2062(68.4)$ & $1343(34.7)$ & $288(24.5)$ & $53,573(85.5)$ & - \\
\hline Unnecessarily restrictive/moderately restrictive & $297(9.9)$ & $272(7.0)$ & $139(11.9)$ & $3227(5.2)$ & - \\
\hline Not enough & $657(21.8)$ & $2256(58.3)$ & $745(63.6)$ & $5825(9.3)$ & - \\
\hline $\begin{array}{l}\text { Self-efficacy in carrying out measures: How confident are } \\
\text { you that you are able and willing to carry out these measures? }\end{array}$ & & & & & $<.001$ \\
\hline Not confident/slightly confident & $138(4.5)$ & $93(2.3)$ & $52(4.4)$ & $3867(6.1)$ & - \\
\hline Moderately confident & $216(7.0)$ & $248(6.3)$ & $195(16.3)$ & $11,470(18.1)$ & - \\
\hline Confident/very confident & $2712(88.5)$ & $3599(91.4)$ & $946(79.3)$ & $48,144(75.8)$ & - \\
\hline \multicolumn{6}{|l|}{$\begin{array}{l}\text { Perceived barriers to carrying out measures: Have any bar- } \\
\text { riers prevented you from adhering to these measures? Do } \\
\text { you have any difficulty getting masks, hand soap, and hand } \\
\text { sanitizer? }\end{array}$} \\
\hline Masks & $1856(60.5)$ & $2547(64.5)$ & $633(52.7)$ & $7736(12.2)$ & $<.001$ \\
\hline Essential job & $381(12.4)$ & $630(16.0)$ & $333(27.8)$ & $16,141(25.4)$ & $<.001$ \\
\hline Family obligations & $201(6.6)$ & $636(16.1)$ & $92(7.7)$ & $5188(8.2)$ & $<.001$ \\
\hline Transportation needs & $49(1.6)$ & $193(4.9)$ & $595(49.6)$ & $15,158(23.8)$ & $<.001$ \\
\hline Hand soap & $142(4.6)$ & $167(4.2)$ & $13(1.1)$ & $384(0.6)$ & $<.001$ \\
\hline Hand sanitizer & $1536(50.0)$ & $2056(52.1)$ & $104(8.7)$ & $2708(4.3)$ & $<.001$ \\
\hline \multicolumn{6}{|l|}{$\begin{array}{l}\text { Cues to action: What are your top three sources of informa- } \\
\text { tion regarding COVID-19? }\end{array}$} \\
\hline News source & $2119(69.0)$ & 1965 (49.8) & $1002(83.4)$ & $50,443(79.3)$ & $<.001$ \\
\hline Social media & $1234(40.2)$ & $1337(33.9)$ & $846(70.4)$ & $39,251(61.7)$ & $<.001$ \\
\hline Central administration officials & $312(10.2)$ & $1155(29.3)$ & $25(2.1)$ & $14,730(23.1)$ & $<.001$ \\
\hline Regional administration officials & $1129(36.8)$ & $567(14.4)$ & $60(5.0)$ & $1387(2.2)$ & $<.001$ \\
\hline
\end{tabular}

${ }^{a}$ Weighted values were calculated by dividing the actual proportion of the country's population by the proportion from the study's sample, then renormalized for each country to ensure weighted and unweighted sample sizes were equal. Due to rounding and missing data $(<5 \%$ for each item), the sum of frequencies and percentages for the sample weighted columns may not equal the country's total sample size.

${ }^{\mathrm{b}} P$ values were calculated using 2 -sided chi-square tests.

${ }^{\mathrm{c}}$ Not available.

${ }^{\mathrm{d}}$ The top four media resources selected by respondents, when asked to pick their top three from the list, are shown. 


\section{Association of HBM Constructs With Handwashing and Social Distancing Behaviors}

In multivariable analyses, individuals with higher self-efficacy were more likely to perform more handwashing practices compared to those with lower self-efficacy $\left(\mathrm{OR}_{\text {United States }} 1.58\right.$,

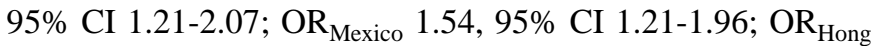
Kong 2.48, 95\% CI 1.80-3.44; $\mathrm{OR}_{\text {Taiwan }} 2.30,95 \%$ CI 2.21-2.39) (see Table 3 ). The significance of other HBM constructs varied by country. Performing more handwashing practices was positively and significantly associated with perceived severity in the United States $\left(\mathrm{OR}_{\text {severity }} 1.33,95 \%\right.$ CI 1.09-1.61), perceived susceptibility in Mexico $\left(\mathrm{OR}_{\text {susceptibility }} 1.23,95 \% \mathrm{CI}\right.$ 1.06-1.42) and Hong Kong ( $\mathrm{OR}_{\text {susceptibility }} 1.44$, 95\% CI 1.11-1.87), and perceived susceptibility and perceived severity in Taiwan $\left(\mathrm{OR}_{\text {susceptibility }} 1.08,95 \%\right.$ CI 1.04-1.12; $\mathrm{OR}_{\text {severity }} 1.24$, 95\% CI 1.20-1.29). In the United States, Mexico, and Taiwan, those who perceived government measures for COVID-19 as restrictive were significantly less likely to handwash compared to those who perceived measures as appropriate or essential $\left(\mathrm{OR}_{\text {United States }} 0.41,95 \% \mathrm{CI} 0.30-0.55 ; \mathrm{OR}_{\text {Mexico }} 0.65,95 \% \mathrm{CI}\right.$ $0.50-0.86 ; \mathrm{OR}_{\text {Taiwan }} 0.82,95 \%$ CI 0.76-0.89). In the United States, non-White respondents were more likely to handwash compared to White or European respondents $\left(\mathrm{OR}_{\text {Hispanic/Latino or }}\right.$ other 3.22, 95\% CI 2.69-3.86; OR Asian $^{2.76,95 \% ~ C I ~ 1.89-4.04) . ~}$ Similar patterns of association for covariates persisted even when we used handwashing time (>20 seconds), another important COVID-19 handwashing behavior, as the binary outcome in the sensitivity analysis (see Multimedia Appendix 5).
Similar to handwashing, individuals with higher self-efficacy were also more likely to practice social distancing compared to those with lower self-efficacy $\left(\mathrm{OR}_{\mathrm{United}}\right.$ States $1.77,95 \% \mathrm{CI}$

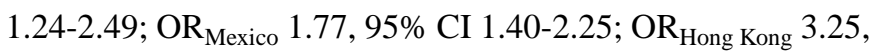
95\% CI 2.32-4.62; OR Taiwan $^{2.58,95 \% ~ C I ~ 2.47-2.68) ~(s e e ~ T a b l e ~}$ 4). Social distancing was also positively associated with perceived severity in the United States $\left(\mathrm{OR}_{\text {severity }} 1.62,95 \% \mathrm{CI}\right.$ 1.24-2.12), Mexico (OR $\mathrm{OR}_{\text {severity }} 1.29,95 \%$ CI 1.11-1.50), and Taiwan ( $\mathrm{OR}_{\text {severity }} 1.17,95 \%$ CI 1.13-1.21). Similarly, in the United States, Mexico, and Taiwan, those who perceived government measures for COVID-19 as restrictive were significantly less likely to practice social distancing compared to those who perceived measures as appropriate or essential $\left(\mathrm{OR}_{\text {United States }} 0.52,95 \% \mathrm{CI} 0.36-0.76 ; \mathrm{OR}_{\text {Mexico }} 0.65,95 \% \mathrm{CI}\right.$ 0.49-0.85; OR $\mathrm{OR}_{\text {Taiwan }} 0.82,95 \%$ CI 0.76-0.88). In the United States, family obligations and transportation needs were associated with fewer social distancing practices $\left(\mathrm{OR}_{\text {family }} 0.25\right.$,

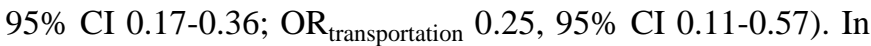
Hong Kong, those who had difficulty obtaining masks were more likely to socially distance $\left(\mathrm{OR}_{\text {masks }} 1.61,95 \% \mathrm{CI}\right.$ 1.23-2.10), but those who had an essential job or transportation needs were less likely to socially distance $\left(\mathrm{OR}_{\text {essential job }} 0.66\right.$, 95\% CI 0.48-0.89; OR transportation $0.67,95 \%$ CI 0.52-0.87). Similarly in Taiwan, those who had an essential job or transportation needs were less likely to socially distance $\left(\mathrm{OR}_{\text {essential job }} 0.71,95 \% \mathrm{CI} 0.68-0.74 ; \mathrm{OR}_{\text {transportation }} 0.85,95 \%\right.$ CI 0.82-0.89). 
Table 3. Multivariable model of health beliefs and handwashing practices by country.

\begin{tabular}{|c|c|c|c|c|c|c|c|c|}
\hline $\begin{array}{l}\text { Characteristic or construct and re- } \\
\text { sponses }\end{array}$ & $\begin{array}{l}\text { United States, } \\
\mathrm{OR}^{\mathrm{a}}(95 \% \mathrm{CI})\end{array}$ & $P$ value & $\begin{array}{l}\text { Mexico, OR } \\
(95 \% \mathrm{CI})\end{array}$ & $P$ value & $\begin{array}{l}\text { Hong Kong, } \\
\text { OR }(95 \% \text { CI) }\end{array}$ & $P$ value & $\begin{array}{l}\text { Taiwan, OR } \\
(95 \% \mathrm{CI})\end{array}$ & $P$ value \\
\hline \multicolumn{9}{|l|}{ Age group (years) } \\
\hline $18-24$ & Reference & & Reference & & Reference & & Reference & \\
\hline $25-34$ & $1.14(0.65-2.03)$ & .70 & $1.15(0.91-1.46)$ & .20 & $2.00(1.14-3.55)$ & .02 & $\begin{array}{l}1.44(1.34- \\
1.55)\end{array}$ & $<.001$ \\
\hline $35-44$ & $1.24(0.72-2.20)$ & .40 & $1.60(1.25-2.04)$ & $<.001$ & $2.15(1.24-3.80)$ & .007 & $\begin{array}{l}2.24(2.09- \\
2.41)\end{array}$ & $<.001$ \\
\hline $45-59$ & $1.91(1.11-3.34)$ & .02 & $1.86(1.47-2.35)$ & $<.001$ & $2.20(1.29-3.82)$ & .004 & $\begin{array}{l}2.66(2.48- \\
2.85)\end{array}$ & $<.001$ \\
\hline $60+$ & $1.10(0.63-1.95)$ & .70 & $1.76(1.37-2.26)$ & $<.001$ & $1.16(0.67-2.03)$ & .60 & $\begin{array}{l}2.96(2.76- \\
3.18)\end{array}$ & $<.001$ \\
\hline \multicolumn{9}{|l|}{ Gender } \\
\hline Female & Reference & & Reference & & Reference & & Reference & \\
\hline Male & $0.84(0.71-1.00)$ & .05 & $1.00(0.87-1.14)$ & .90 & $1.09(0.85-1.40)$ & .50 & $\begin{array}{l}0.69(0.66- \\
0.71)\end{array}$ & $<.001$ \\
\hline Other $^{\mathrm{b}}$ & $1.52(0.62-3.93)$ & .40 & $1.09(0.56-2.11)$ & .80 & $1.73(0.80-3.84)$ & .20 & $\begin{array}{l}1.06(0.96- \\
1.17)\end{array}$ & .02 \\
\hline \multicolumn{9}{|l|}{ Race or ethnicity } \\
\hline White or European & Reference & & $N / A^{c}$ & & N/A & & N/A & \\
\hline Hispanic/Latino or other ${ }^{\mathrm{d}}$ & $3.22(2.69-3.86)$ & $<.001$ & N/A & N/A & $\mathrm{N} / \mathrm{A}$ & N/A & N/A & N/A \\
\hline Asian & $2.76(1.89-4.04)$ & $<.001$ & $\mathrm{~N} / \mathrm{A}$ & N/A & $\mathrm{N} / \mathrm{A}$ & $\mathrm{N} / \mathrm{A}$ & $\mathrm{N} / \mathrm{A}$ & N/A \\
\hline \multicolumn{9}{|l|}{ Education } \\
\hline Below college & Reference & & Reference & & Reference & & Reference & \\
\hline College and above & $0.99(0.71-1.40)$ & .90 & $1.14(0.95-1.36)$ & .20 & $1.13(0.84-1.53)$ & .40 & $\begin{array}{l}0.84(0.80- \\
0.88)\end{array}$ & $<.001$ \\
\hline \multicolumn{9}{|l|}{$\begin{array}{l}\text { Perceived susceptibility of infec- } \\
\text { tion }\end{array}$} \\
\hline Not likely/slightly likely & Reference & & Reference & & Reference & & Reference & \\
\hline Moderately to very likely & $1.12(0.95-1.33)$ & .20 & $1.23(1.06-1.42)$ & .006 & $1.44(1.11-1.87)$ & .007 & $\begin{array}{l}1.08(1.04- \\
1.12)\end{array}$ & $<.001$ \\
\hline \multicolumn{9}{|l|}{ Perceived severity of COVID-19 } \\
\hline Not afraid/slightly afraid & Reference & & Reference & & Reference & & Reference & \\
\hline Moderately to very afraid & $1.33(1.09-1.61)$ & .005 & $1.06(0.91-1.22)$ & .50 & $1.22(0.90-1.65)$ & .20 & $\begin{array}{l}1.24(1.20- \\
1.29)\end{array}$ & $<.001$ \\
\hline \multicolumn{9}{|l|}{$\begin{array}{l}\text { Perceived benefits of handwashing } \\
\text { measures }\end{array}$} \\
\hline $\begin{array}{l}\text { Unnecessarily restrictive/moder- } \\
\text { ately restrictive }\end{array}$ & $0.41(0.30-0.55)$ & $<.001$ & $0.65(0.50-0.86)$ & .002 & $0.65(0.41-1.02)$ & .06 & $\begin{array}{l}0.82(0.76- \\
0.89)\end{array}$ & $<.001$ \\
\hline Appropriate/essential & Reference & & Reference & & Reference & & Reference & \\
\hline Not enough & $1.49(1.23-1.82)$ & $<.001$ & $0.97(0.84-1.12)$ & .70 & $0.77(0.56-1.07)$ & .12 & $\begin{array}{l}0.91(0.86- \\
0.96)\end{array}$ & .001 \\
\hline \multicolumn{9}{|l|}{$\begin{array}{l}\text { Self-efficacy in carrying out } \\
\text { handwashing measures }\end{array}$} \\
\hline $\begin{array}{l}\text { Not confident/moderately confi- } \\
\text { dent }\end{array}$ & Reference & & Reference & & Reference & & Reference & \\
\hline Confident/very confident & $1.58(1.21-2.07)$ & $<.001$ & $1.54(1.21-1.96)$ & $<.001$ & $2.48(1.80-3.44)$ & $<.001$ & $\begin{array}{l}2.30(2.21- \\
2.39)\end{array}$ & $<.001$ \\
\hline
\end{tabular}




\begin{tabular}{|c|c|c|c|c|c|c|c|c|}
\hline $\begin{array}{l}\text { Characteristic or construct and re- } \\
\text { sponses }\end{array}$ & $\begin{array}{l}\text { United States, } \\
\mathrm{OR}^{\mathrm{a}}(95 \% \mathrm{CI})\end{array}$ & $P$ value & $\begin{array}{l}\text { Mexico, OR } \\
(95 \% \mathrm{CI})\end{array}$ & $P$ value & $\begin{array}{l}\text { Hong Kong, } \\
\text { OR }(95 \% \mathrm{CI})\end{array}$ & $P$ value & $\begin{array}{l}\text { Taiwan, OR } \\
(95 \% \mathrm{CI})\end{array}$ & $P$ value \\
\hline \multicolumn{9}{|l|}{$\begin{array}{l}\text { Perceived barriers to following } \\
\text { handwashing measures (reference } \\
\text { is "no") }\end{array}$} \\
\hline Hand soap & $0.73(0.49-1.07)$ & .11 & $1.35(0.98-1.87)$ & .07 & $7.59(1.88-53.9)$ & .01 & $\begin{array}{l}1.01(0.81- \\
1.27)\end{array}$ & .90 \\
\hline Hand sanitizer & $0.88(0.74-1.03)$ & .11 & $1.01(0.88-1.15)$ & .90 & $1.14(0.74-1.77)$ & .50 & $\begin{array}{l}0.86(0.79- \\
0.94)\end{array}$ & $<.001$ \\
\hline \multicolumn{9}{|l|}{ Cues to action (reference is "no") $\mathrm{e}$} \\
\hline News source & $0.77(0.64-0.92)$ & .003 & $0.80(0.70-0.92)$ & .001 & $0.97(0.69-1.35)$ & .80 & $\begin{array}{l}0.95(0.91- \\
0.99)\end{array}$ & .02 \\
\hline Social media & $0.60(0.50-0.71)$ & $<.001$ & $0.77(0.67-0.89)$ & $<.001$ & $0.79(0.60-1.05)$ & .10 & $\begin{array}{l}0.86(0.83- \\
0.89)\end{array}$ & $<.001$ \\
\hline Central administration officials & $1.32(1.01-1.74)$ & .05 & $0.84(0.73-0.98)$ & .02 & $1.27(0.55-3.02)$ & 60 & $\begin{array}{l}0.99(0.95- \\
1.03)\end{array}$ & .70 \\
\hline Regional administration officials & $0.63(0.52-0.75)$ & $<.001$ & $0.83(0.69-1.00)$ & .05 & $0.42(0.22-0.77)$ & .007 & $\begin{array}{l}1.08(0.96- \\
1.21)\end{array}$ & .20 \\
\hline
\end{tabular}

${ }^{a}$ OR: odds ratio; models were run using weighted data, which were calculated by dividing the actual proportion of the country's population by the proportion from the study's sample, then renormalized for each country to ensure weighted and unweighted sample sizes were equal.

${ }^{\mathrm{b}}$ Responses of other gender include individuals who chose nonbinary/third gender, prefer not to say, or other ( $<3 \%$ of total responses).

${ }^{\mathrm{c}} \mathrm{N} / \mathrm{A}$ : not applicable; race or ethnicity was not adjusted for these countries as the majority identified as the same race or ethnicity.

${ }^{d}$ Responses of other race or ethnicity include individuals who are Black or African American, American Indian or Alaska Native, Native Hawaiian or other Pacific Islander, or other. Categories were collapsed due to low numbers ( $<2 \%$ of total responses).

${ }^{\mathrm{e}}$ The top four media resources selected by respondents, when asked to pick their top three from the list, are shown. 
Table 4. Multivariable model of health beliefs and social distancing practices by country.

\begin{tabular}{|c|c|c|c|c|c|c|c|c|}
\hline $\begin{array}{l}\text { Characteristic or construct and respons- } \\
\text { es }\end{array}$ & $\begin{array}{l}\text { United States, } \\
\text { OR }(95 \% \mathrm{CI})^{\mathrm{a}}\end{array}$ & $P$ value & $\begin{array}{l}\text { Mexico, OR } \\
(95 \% \mathrm{CI})\end{array}$ & $P$ value & $\begin{array}{l}\text { Hong Kong, } \\
\text { OR }(95 \% \mathrm{CI})\end{array}$ & $P$ value & $\begin{array}{l}\text { Taiwan, OR } \\
(95 \% \mathrm{CI})\end{array}$ & $P$ value \\
\hline \multicolumn{9}{|l|}{ Age group (years) } \\
\hline $18-24$ & Reference & & Reference & & Reference & & Reference & \\
\hline $25-34$ & $1.21(0.52-2.66)$ & .60 & $\begin{array}{l}0.70(0.54- \\
0.90)\end{array}$ & .006 & $\begin{array}{l}1.19(0.68- \\
2.08)\end{array}$ & .50 & $\begin{array}{l}1.39(1.29- \\
1.50)\end{array}$ & $<.001$ \\
\hline $35-44$ & $1.61(0.71-3.53)$ & .20 & $\begin{array}{l}0.69(0.53- \\
0.89)\end{array}$ & .005 & $\begin{array}{l}1.09(0.63- \\
1.89)\end{array}$ & .80 & $\begin{array}{l}1.82(1.69- \\
1.96)\end{array}$ & $<.001$ \\
\hline $45-59$ & $1.67(0.72-3.65)$ & .20 & $\begin{array}{l}0.67(0.52- \\
0.86)\end{array}$ & .002 & $\begin{array}{l}1.17(0.69- \\
1.99)\end{array}$ & .60 & $\begin{array}{l}1.93(1.80- \\
2.07)\end{array}$ & $<.001$ \\
\hline $60+$ & $3.30(1.42-7.31)$ & .004 & $\begin{array}{l}0.52(0.40- \\
0.68)\end{array}$ & $<.001$ & $\begin{array}{l}0.56(0.32- \\
0.97)\end{array}$ & .04 & $\begin{array}{l}1.89(1.76- \\
2.03)\end{array}$ & $<.001$ \\
\hline \multicolumn{9}{|l|}{ Gender } \\
\hline Female & Reference & & Reference & & Reference & & Reference & \\
\hline Male & $1.36(1.05-1.75)$ & .02 & $\begin{array}{l}1.14(0.99- \\
1.31)\end{array}$ & .07 & $\begin{array}{l}1.04(0.81- \\
1.34)\end{array}$ & .80 & $\begin{array}{l}1.03(1.00- \\
1.07)\end{array}$ & .07 \\
\hline Other $^{\mathrm{b}}$ & $1.68(0.47-8.23)$ & .50 & $\begin{array}{l}1.02(0.52- \\
2.06)\end{array}$ & .90 & $\begin{array}{l}0.38(0.15- \\
0.87)\end{array}$ & .03 & $\begin{array}{l}0.92(0.83- \\
1.01)\end{array}$ & .10 \\
\hline \multicolumn{9}{|l|}{ Race or ethnicity } \\
\hline White or European & Reference & & $N / A^{c}$ & & N/A & & N/A & \\
\hline Hispanic/Latino or other ${ }^{\mathrm{d}}$ & $0.46(0.35-0.61)$ & $<.001$ & N/A & N/A & N/A & N/A & N/A & N/A \\
\hline Asian & $0.78(0.44-1.42)$ & .40 & N/A & N/A & N/A & N/A & N/A & N/A \\
\hline \multicolumn{9}{|l|}{ Education } \\
\hline Below college & Reference & & Reference & & Reference & & Reference & \\
\hline College and above & $0.60(0.36-0.96)$ & .04 & $\begin{array}{l}1.32(1.10- \\
1.60)\end{array}$ & .003 & $\begin{array}{l}1.13(0.83- \\
1.54)\end{array}$ & .40 & $\begin{array}{l}1.17(1.12- \\
1.24)\end{array}$ & $<.001$ \\
\hline \multicolumn{9}{|l|}{ Reduced income } \\
\hline No & Reference & & Reference & & Reference & & Reference & \\
\hline Yes & $0.60(0.46-0.78)$ & $<.001$ & $\begin{array}{l}0.95(0.83- \\
1.10)\end{array}$ & .50 & $\begin{array}{l}0.98(0.74- \\
1.30)\end{array}$ & .90 & $\begin{array}{l}1.07(1.03- \\
1.12)\end{array}$ & .002 \\
\hline \multicolumn{9}{|l|}{ Perceived susceptibility of infection } \\
\hline Not likely/slightly likely & Reference & & Reference & & Reference & & Reference & \\
\hline Moderately to very likely & $1.11(0.86-1.44)$ & .40 & $\begin{array}{l}1.02(0.88- \\
1.19)\end{array}$ & .80 & $\begin{array}{l}0.76(0.58- \\
0.99)\end{array}$ & .05 & $\begin{array}{l}0.94(0.90- \\
0.97)\end{array}$ & $<.001$ \\
\hline \multicolumn{9}{|l|}{ Perceived severity of COVID-19 } \\
\hline Not afraid/slightly afraid & Reference & & Reference & & Reference & & Reference & \\
\hline Moderately to very afraid & $1.62(1.24-2.12)$ & $<.001$ & $\begin{array}{l}1.29(1.11- \\
1.50)\end{array}$ & .001 & $\begin{array}{l}1.34(0.99- \\
1.84)\end{array}$ & .06 & $\begin{array}{l}1.17(1.13- \\
1.21)\end{array}$ & $<.001$ \\
\hline \multicolumn{9}{|l|}{$\begin{array}{l}\text { Perceived benefits of social distanc- } \\
\text { ing measures }\end{array}$} \\
\hline $\begin{array}{l}\text { Unnecessarily restrictive/moderately } \\
\text { restrictive }\end{array}$ & $0.52(0.36-0.76)$ & $<.001$ & $\begin{array}{l}0.65(0.49- \\
0.85)\end{array}$ & .002 & $\begin{array}{l}1.24(0.79- \\
1.96)\end{array}$ & .40 & $\begin{array}{l}0.82(0.76- \\
0.88)\end{array}$ & $<.001$ \\
\hline Appropriate/essential & Reference & & Reference & & Reference & & Reference & \\
\hline Not enough & $1.72(1.24-2.42)$ & .001 & $\begin{array}{l}1.22(1.05- \\
1.41)\end{array}$ & .01 & $\begin{array}{l}1.04(0.74- \\
1.46)\end{array}$ & .80 & $\begin{array}{l}1.05(0.99- \\
1.11)\end{array}$ & .13 \\
\hline \multicolumn{9}{|l|}{$\begin{array}{l}\text { Self-efficacy in carrying out social } \\
\text { distancing measures }\end{array}$} \\
\hline Not confident/moderately confident & Reference & & Reference & & Reference & & Reference & \\
\hline
\end{tabular}




\begin{tabular}{|c|c|c|c|c|c|c|c|c|}
\hline $\begin{array}{l}\text { Characteristic or construct and respons- } \\
\text { es }\end{array}$ & $\begin{array}{l}\text { United States, } \\
\text { OR }(95 \% \mathrm{CI})^{\mathrm{a}}\end{array}$ & $P$ value & $\begin{array}{l}\text { Mexico, OR } \\
(95 \% \text { CI })\end{array}$ & $P$ value & $\begin{array}{l}\text { Hong Kong, } \\
\text { OR ( } 95 \% \mathrm{CI})\end{array}$ & $P$ value & $\begin{array}{l}\text { Taiwan, OR } \\
(95 \% \text { CI })\end{array}$ & $P$ value \\
\hline Confident/very confident & $1.77(1.24-2.49)$ & .001 & $\begin{array}{l}1.77(1.40- \\
2.25)\end{array}$ & $<.001$ & $\begin{array}{l}3.25(2.32- \\
4.62)\end{array}$ & $<.001$ & $\begin{array}{l}2.58(2.47- \\
2.68)\end{array}$ & $<.001$ \\
\hline
\end{tabular}

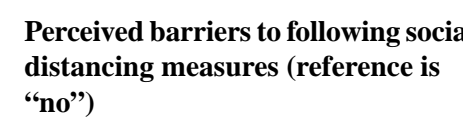

\begin{tabular}{|c|c|c|c|c|c|c|c|c|}
\hline Masks & $0.95(0.73-1.23)$ & .70 & $\begin{array}{l}1.11(0.96- \\
1.28)\end{array}$ & .20 & $\begin{array}{l}1.61(1.23- \\
2.10)\end{array}$ & $<.001$ & $\begin{array}{l}0.92(0.88- \\
0.97)\end{array}$ & .002 \\
\hline Essential job & $0.86(0.61-1.23)$ & .40 & $\begin{array}{l}0.85(0.71- \\
1.03)\end{array}$ & .09 & $\begin{array}{l}0.66(0.48- \\
0.89)\end{array}$ & .007 & $\begin{array}{l}0.71(0.68- \\
0.74)\end{array}$ & $<.001$ \\
\hline Family obligations & $0.25(0.17-0.36)$ & $<.001$ & $\begin{array}{l}0.84(0.70- \\
1.01)\end{array}$ & .06 & $\begin{array}{l}0.80(0.50- \\
1.29)\end{array}$ & .40 & $\begin{array}{l}0.97(0.92- \\
1.04)\end{array}$ & .40 \\
\hline Transportation needs & $0.25(0.11-0.57)$ & $<.001$ & $\begin{array}{l}0.78(0.57- \\
1.06)\end{array}$ & .11 & $\begin{array}{l}0.67(0.52- \\
0.87)\end{array}$ & .002 & $\begin{array}{l}0.85(0.82- \\
0.89)\end{array}$ & $<.001$ \\
\hline \multicolumn{9}{|l|}{ Uues to action (reference is "no") ${ }^{\mathrm{e}}$} \\
\hline News source & $1.58(1.22-2.04)$ & $<.001$ & $\begin{array}{l}0.96(0.84- \\
1.10)\end{array}$ & .60 & $\begin{array}{l}0.94(0.66- \\
1.33)\end{array}$ & .70 & $\begin{array}{l}0.93(0.89- \\
0.97)\end{array}$ & $<.001$ \\
\hline Social media & $0.53(0.41-0.68)$ & $<.001$ & $\begin{array}{l}0.92(0.80- \\
1.07)\end{array}$ & .30 & $\begin{array}{l}0.85(0.64- \\
1.13)\end{array}$ & .30 & $\begin{array}{l}0.91(0.88- \\
0.95)\end{array}$ & $<.001$ \\
\hline Central administration officials & $1.15(0.78-1.75)$ & .50 & $\begin{array}{l}1.04(0.89- \\
1.22)\end{array}$ & .60 & $\begin{array}{l}1.33(0.56- \\
3.13)\end{array}$ & .50 & $\begin{array}{l}1.15(1.11- \\
1.20)\end{array}$ & $<.001$ \\
\hline Regional administration officials & $0.70(0.53-0.92)$ & .01 & $\begin{array}{l}1.20(0.98- \\
1.46)\end{array}$ & .08 & $\begin{array}{l}1.59(0.90- \\
2.83)\end{array}$ & .11 & $\begin{array}{l}1.07(0.96- \\
1.20)\end{array}$ & .20 \\
\hline
\end{tabular}

aOR: odds ratio; models were run using weighted data, which were calculated by dividing the actual proportion of the country's population by the proportion from the study's sample, then renormalized for each country to ensure weighted and unweighted sample sizes were equal.

${ }^{\mathrm{b}}$ Responses of other gender include individuals who chose nonbinary/third gender, prefer not to say, or other ( $<3 \%$ of total responses).

${ }^{\mathrm{c}}$ N/A: not applicable; race or ethnicity was not adjusted for these countries as the majority identified as the same race or ethnicity.

${ }^{\mathrm{d}}$ Responses of other race or ethnicity include individuals who are Black or African American, American Indian or Alaska Native, Native Hawaiian or other Pacific Islander, or other. Categories were collapsed due to low numbers (<2\% of total responses).

${ }^{\mathrm{e}}$ The top four media resources selected by respondents, when asked to pick their top three from the list, are shown.

\section{Discussion}

\section{Principal Findings}

In this international study to examine COVID-19-related health behaviors using the HBM, we showed that respondents from the United States practiced the most social distancing, while those from Taiwan practiced the most handwashing. Despite these differences in health behaviors, self-efficacy was a significant predictor in all four countries. Our findings may be explained by the strictness and timing of government policies, the number of confirmed infection cases in each country, individual beliefs, and cultural context.

In the context of government interventions, Taiwan's early border control, case identification, isolation of suspected cases, and resource allocation led to recommendations for social distancing, though not strictly enforced [27]. Similarly, Hong Kong's early identification and strict quarantine of suspected cases resulted in regulations that prohibited large public gatherings but otherwise maintained regular activities [28,29]. On the other hand, 43 US states issued lockdown orders between mid-March and early April 2020, each lasting until the end of April at the minimum [30]. Mexico issued similar orders on March 26, 2020,with the strictest measures lasting until the end of May 2020 [31]. These varying degrees of strictness and timing of government interventions among the four countries may have attributed to increased social distancing in the United States and Mexico compared to Hong Kong and Taiwan.

Furthermore, at the start of our study period on April 11, 2020, the World Health Organization Situation Report recorded 1.6 million confirmed COVID-19 cases, with more than 99,000 deaths in over 200 countries and territories [32]. This included 461,275 confirmed cases in the United States, 3441 in Mexico, 1001 in Hong Kong, and 382 in Taiwan [26,32,33]. By the end of our study period on May 1, 2020, the numbers of cases and deaths had doubled worldwide [32]. The United States and Mexico saw a $124 \%$ and $417 \%$ increase in the number of confirmed COVID-19 cases, respectively, while Taiwan and Hong Kong reported only a $6.8 \%$ and $3.9 \%$ increase, respectively $[26,32,33]$. The rapid increase in confirmed cases in the United States and Mexico compared to Hong Kong and Taiwan likely also played a role in understanding handwashing and social distancing behaviors.

Among the HBM constructs, our study found that self-efficacy was the strongest positive predictor for both handwashing and social distancing in all countries. These findings were largely consistent with previous studies that examined preventative 
behaviors for cancers using the HBM $[34,35]$. Although a review of HBM studies suggested that the construct of perceived barriers was the best individual predictor across different types of studies and behaviors, self-efficacy can be seen as an important factor in overcoming the barriers to taking actions [17]. Perceived barriers were not significantly associated with hand hygiene, possibly because difficulties accessing water, soap, and hand sanitizer were less common among our survey respondents. For instance, Mexico is an upper-middle-income country and in some regions and communities these items might not be readily available; however, the population we reached through social media may be comparable to the populations we assessed from the other high-income countries [36]. For social distancing behaviors, having transportation needs was consistently associated with practicing less social distancing. This is especially relevant in Hong Kong and Taiwan, where public transportation is heavily utilized with their population densities of 6690 and 652 persons per square kilometer, respectively $[37,38]$. In their most densely populated districts, these numbers are even higher at 57,250 and 27,418 persons per square kilometer, respectively [37,39]. It is also important to note that we treated each perceived barrier as a unique covariate in the model to assess the most relevant barriers to social distancing, which may differ from other studies. Moreover, given that our respondents were mostly well-educated social media users, the true proportion of individuals with perceived barriers in our study was likely underestimated.

Previous studies have also suggested perceived susceptibility to be a good predictor for preventative behaviors [17]. In our study, perceived susceptibility was, overall, a significant positive predictor for practicing more handwashing. Perceived severity was also a strong predictor for both handwashing and social distancing in the United States and Taiwan, which may have been influenced by the worldwide news coverage and the strictness of government interventions. The associations found between perceived benefits and health behaviors may be tied to the timing of policies in each country and overall trust in the government. Cues to action, measured as types of media publicity, were not significant for predicting behavioral change in our model.

Modifiable factors that influence individual beliefs, such as culture and prior knowledge, are important to consider. In Hong Kong and Taiwan, wide adoption of preventative behaviors after the 2003 SARS outbreak may have better prepared residents for COVID-19, which may explain their greater sense of self-efficacy in handwashing and social distancing compared to other countries. Many residents were already taking regular individual actions, practicing good hand hygiene for infection control or wearing masks to counter air pollution when the pandemic hit. In fact, the study team received several emails from respondents in Taiwan and Hong Kong, noting that they had practiced handwashing prior to the pandemic because they were taught to do so as children. For this study, we were unable to statistically account for social factors and prior knowledge in our analyses, but future studies should consider including them into models to assess the influence of social and cultural factors on preventative health behaviors.

\section{Using Social Media for Recruitment During COVID-19}

Our study may also provide insight into the effect of using social media recruitment strategies to reach a large audience. Given the rapidly evolving information, beliefs, and policies surrounding COVID-19, internet sampling allowed us to (1) capture real-time data simultaneously in different countries in a short time span, (2) reach a large number of participants in lockdown, and (3) overcome financial limitations [40]. The combination of boosting and sharing of social media posts allowed us to effectively target specific populations and locations while also reaching a larger audience, as was evident by the number of respondents from Taiwan. Our findings expand on recent COVID-19 studies from the United States and Taiwan that used similar methods to assess other COVID-19 attitudes, behaviors, and knowledge among different populations [41-43].

\section{Limitations}

There are limitations to this study. Firstly, we used convenience sampling to recruit participants, which could have introduced potential sample selection bias. For example, we found an underrepresentation of populations with lower educational levels. This may have resulted in an overestimation of adherence rates and underestimation of perceived barriers. However, in multivariate analysis, education was not statistically associated with handwashing or social distancing practices. To best address the imbalances in our sample, we conducted poststratification weighting by age and gender, as well as race or ethnicity for the United States, to improve the generalizability of our results, although we understand that this does not make up for all of the differences [44]. Secondly, we had a disproportionately larger sample size in Taiwan relative to other countries [45]. However, since our main multivariable analyses were country specific, this would not likely affect the estimates found in other countries. Finally, there are weaknesses within the HBM itself. The HBM does not account for a person's nonhealth-related beliefs or determinants that dictate a person's acceptance of a health behavior. Health behaviors can also be learned through modeling as explained by other behavior change theories, such as the social cognitive theory (SCT); for instance, residents in Taiwan and Hong Kong might regularly wear masks and practice hand hygiene from observing those around them [46]. Self-efficacy, the strongest predictor in our study, is also known to play a large role in health behavior in the context of the SCT. However, we did not use SCT in our study because the theory's heavy emphasis on the process of learning disregards an individual's perception about COVID-19 as well as their motivations behind handwashing and social distancing behaviors. The collection of data on health beliefs, which the HBM encompasses, is important for the planning of interventions that can then be targeted to each country's specific needs.

\section{Conclusions}

Overall, our findings revealed that certain health belief constructs were independently associated with social distancing and handwashing behaviors. In the context of controlling the continued spread of COVID-19, self-efficacy is a significant predictor that can be easily targeted and modified by public health officials and educators. Policies and communications 
that address relevant health beliefs can facilitate adoption of necessary actions for preventing COVID-19.

\section{Acknowledgments}

We would like to thank Beth Duff-Brown for disseminating the survey via social media and Judy Sun for helping with the Mandarin translation of study-related materials.

\section{Conflicts of Interest}

None declared.

\section{Multimedia Appendix 1}

Survey items.

[DOCX File, 21 KB-Multimedia Appendix 1]

\section{Multimedia Appendix 2}

Comparison of unweighted and weighted sample characteristics in the United States and Mexico relative to country population estimates.

[DOCX File, 22 KB-Multimedia Appendix 2]

\section{Multimedia Appendix 3}

Comparison of unweighted and weighted sample characteristics in Hong Kong and Taiwan relative to country population estimates. [DOCX File, 22 KB-Multimedia Appendix 3]

\section{Multimedia Appendix 4}

Multivariable models assessing handwashing and social distancing practices by country.

[DOCX File, 16 KB-Multimedia Appendix 4]

\section{Multimedia Appendix 5}

Multivariable models of health beliefs and handwashing time ( $>20$ seconds) by country.

[DOCX File, 19 KB-Multimedia Appendix 5]

\section{References}

1. COVID-19 Strategy Update. Geneva, Switzerland: World Health Organization; 2020 Apr 14. URL: https://www.who.int/ docs/default-source/coronaviruse/covid-strategy-update-14april2020.pdf [accessed 2020-06-14]

2. COVID-19 impact on education. UNESCO. 2020. URL: https://en.unesco.org/covid19/educationresponse [accessed 2020-06-14]

3. Rashid H, Ridda I, King C, Begun M, Tekin H, Wood JG, et al. Evidence compendium and advice on social distancing and other related measures for response to an influenza pandemic. Paediatr Respir Rev 2015 Mar;16(2):119-126. [doi: 10.1016/j.prrv.2014.01.003] [Medline: 24630149]

4. Hsiang S, Allen D, Annan-Phan S, Bell K, Bolliger I, Chong T, et al. The effect of large-scale anti-contagion policies on the COVID-19 pandemic. Nature 2020 Jun 08;584(7820):262-267. [doi: 10.1038/s41586-020-2404-8] [Medline: 32512578]

5. Blendon RJ, Koonin LM, Benson JM, Cetron MS, Pollard WE, Mitchell EW, et al. Public response to community mitigation measures for pandemic influenza. Emerg Infect Dis 2008 May;14(5):778-786 [FREE Full text] [doi: 10.3201/eid1405.071437] [Medline: 18439361]

6. Jarvis CI, Van Zandvoort K, Gimma A, Prem K, CMMID COVID-19 Working Group, Klepac P, et al. Quantifying the impact of physical distance measures on the transmission of COVID-19 in the UK. BMC Med 2020 May 07;18(1):124 [FREE Full text] [doi: 10.1186/s12916-020-01597-8] [Medline: 32375776]

7. Zhong B, Luo W, Li H, Zhang Q, Liu X, Li W, et al. Knowledge, attitudes, and practices towards COVID-19 among Chinese residents during the rapid rise period of the COVID-19 outbreak: A quick online cross-sectional survey. Int J Biol Sci 2020;16(10):1745-1752 [FREE Full text] [doi: 10.7150/ijbs.45221] [Medline: 32226294]

8. Briscese G, Lacetera N, Macis M, Tonin M. Expectations, Reference Points, and Compliance With COVID-19 Social Distancing Measures. Cambridge, MA: National Bureau of Economic Research; 2020 Mar. URL: https://www.nber.org/ system/files/working papers/w26916/w26916.pdf [accessed 2021-02-21] 
9. Bavel JJV, Baicker K, Boggio PS, Capraro V, Cichocka A, Cikara M, et al. Using social and behavioural science to support COVID-19 pandemic response. Nat Hum Behav 2020 May;4(5):460-471. [doi: 10.1038/s41562-020-0884-z] [Medline: $\underline{32355299]}$

10. Digital 2020: The United States of America. DataReportal. 2020 Feb 11. URL: https://datareportal.com/reports/ digital-2020-united-states-of-america [accessed 2020-08-21]

11. Digital 2020: Mexico. DataReportal. 2020 Feb 11. URL: https://datareportal.com/reports/digital-2020-mexico [accessed 2020-08-21]

12. Digital 2020: Hong Kong. DataReportal. 2020 Feb 13. URL: https://datareportal.com/reports/digital-2020-hong-kong [accessed 2020-08-21]

13. Digital 2020: Taiwan. DataReportal. 2020 Feb 18. URL: https://datareportal.com/reports/digital-2020-taiwan [accessed 2020-08-21]

14. Leiner DJ. Our research's breadth lives on convenience samples: A case study of the online respondent pool "SoSci Panel". Stud Commun Media 2016 Apr;5(4):367-396 [FREE Full text] [doi: 10.5771/2192-4007-2016-4-367]

15. Kennedy C, Hartig H. Response rates in telephone surveys have resumed their decline. Pew Research Center. Washington, DC: Pew Research Center; 2019 Feb 27. URL: https://www.pewresearch.org/fact-tank/2019/02/27/ response-rates-in-telephone-surveys-have-resumed-their-decline/ [accessed 2020-06-14]

16. Lavrakas PJ. Surveys by telephone. In: Donsbach W, Traugott MW, editors. The SAGE Handbook of Public Opinion Research. London, UK: SAGE Publications Ltd; 2008:249-261.

17. Champion VL, Skinner CS. The health belief model. In: Glanz K, Rimer BK, Viswanath K, editors. Health Behavior and Health Education: Theory, Research, and Practice. San Francisco, CA: Jossey-Bass; 2008:45-65.

18. ACS demographic and housing estimates. United States Census Bureau. 2018. URL: https://data.census.gov/cedsci/ table?q=race $\&$ hidePreview=false $\&$ tid=ACSDP1Y2018.DP05\&vintage=2018 [accessed 2020-06-24]

19. International Data Base (IDB). United States Census Bureau. URL: https://www.census.gov/data-tools/demo/idb/\#/country? YR ANIM=2020\&FIPS SINGLE= MX\&dashPages=BYAGE\&COUNTRY YEAR=2020\&ageGroup=5Y [accessed 2021-02-22]

20. Hong Kong Census and Statistics Department. Main tables. 2016 Population By-census. 2016. URL: https://www. bycensus2016.gov.hk/en/bc-mt.html [accessed 2020-06-24]

21. 2010 population and housing census. The Directorate General of Budget, Accounting and Statistics, Executive Yuan, Republic of China (Taiwan). 2010. URL: https://census.dgbas.gov.tw/PHC2010/english/rehome.htm [accessed 2020-06-24]

22. Royal KD. Survey research methods: A guide for creating post-stratification weights to correct for sample bias. Educ Health Prof 2019;2(1):48-50. [doi: 10.4103/ehp.ehp_8_19]

23. Centers for Disease Control and Prevention. 2020. URL: https://www.cdc.gov/coronavirus/2019-ncov/prevent-getting-sick/ prevention.html [accessed 2020-06-24]

24. Quédate en casa. Gobierno de México. 2020. URL: https://coronavirus.gob.mx/quedate-en-casa/ [accessed 2020-06-24]

25. Health advice. The Government of the Hong Kong Special Administrative Region. 2020. URL: https://www. coronavirus.gov.hk/eng/health-advice.html [accessed 2020-06-24]

26. Taiwan Centers for Disease Control. 2020. URL: https://www.cdc.gov.tw/En [accessed 2020-06-14]

27. Wang CJ, Ng CY, Brook RH. Response to COVID-19 in Taiwan: Big data analytics, new technology, and proactive testing. JAMA 2020 Apr 14;323(14):1341-1342. [doi: 10.1001/jama.2020.3151] [Medline: 32125371]

28. Cheng VCC, Wong S, Chen JHK, Yip CCY, Chuang VWM, Tsang OTY, et al. Escalating infection control response to the rapidly evolving epidemiology of the coronavirus disease 2019 (COVID-19) due to SARS-CoV-2 in Hong Kong. Infect Control Hosp Epidemiol 2020 May;41(5):493-498 [FREE Full text] [doi: 10.1017/ice.2020.58] [Medline: 32131908]

29. New requirements to reduce gatherings. The Government of the Hong Kong Special Administrative Region. 2020. URL: https://www.coronavirus.gov.hk/eng/reduce-gatherings.html [accessed 2020-06-14]

30. COVID-19 policy tracker. MultiState. 2020. URL: https://www.multistate.us/pages/covid-19-policy-tracker [accessed 2020-06-14]

31. COVID-19 information for US citizens in Mexico. US Embassy \& Consulates in Mexico. 2020. URL: https://mx. usembassy.gov/u-s-citizen-services/covid-19-information/ [accessed 2020-06-14]

32. Coronavirus disease (COVID-19) weekly epidemiological update and weekly operational update. World Health Organization. 2020. URL: https://www.who.int/emergencies/diseases/novel-coronavirus-2019/situation-reports [accessed 2020-06-14]

33. Latest situation of cases of COVID-19 (as of 14 June 2020). Centre for Health Protection, The Government of the Hong Kong Special Administrative Region. 2020 Jun. URL: https://www.chp.gov.hk/files/pdf/local_situation_covid19_en.pdf [accessed 2020-06-14]

34. Dewi T, Massar K, Ruiter R, Leonardi T. Determinants of breast self-examination practice among women in Surabaya, Indonesia: An application of the health belief model. BMC Public Health 2019 Nov 27;19(1):1581 [FREE Full text] [doi: 10.1186/s12889-019-7951-2] [Medline: 31775697]

35. Kasparian NA, Bränström R, Chang Y, Affleck P, Aspinwall LG, Tibben A, Melanoma Genetics Consortium (GenoMEL). Skin examination behavior: The role of melanoma history, skin type, psychosocial factors, and region of residence in 
determining clinical and self-conducted skin examination. Arch Dermatol 2012 Oct;148(10):1142-1151 [FREE Full text] [doi: 10.1001/archdermatol.2012.1817] [Medline: 22801744]

36. World Bank country and lending groups. The World Bank. 2020. URL: https://datahelpdesk.worldbank.org/knowledgebase/ articles/906519-world-bank-country-and-lending-groups [accessed 2020-06-30]

37. Hong Kong: The Facts - Population. The Hong Kong Special Administrative Region Government. 2015 Apr. URL: https:/ /www.gov.hk/en/about/abouthk/factsheets/docs/population.pdf [accessed 2020-06-21]

38. Latest indicators. National Statistics, Republic of China (Taiwan). 2020. URL: https://eng.stat.gov.tw/point.asp?index=9 [accessed 2020-06-21]

39. Demographic overview. Taipei City Government. 2017. URL: https://english.gov.taipei/cp.aspx?n=C619997124A6D293 [accessed 2020-06-21]

40. Ali SH, Foreman J, Capasso A, Jones AM, Tozan Y, DiClemente RJ. Social media as a recruitment platform for a nationwide online survey of COVID-19 knowledge, beliefs, and practices in the United States: Methodology and feasibility analysis. BMC Med Res Methodol 2020 May 13;20(1):116 [FREE Full text] [doi: 10.1186/s12874-020-01011-0] [Medline: 32404050]

41. Oosterhoff B, Palmer CA. Attitudes and psychological factors associated with news monitoring, social distancing, disinfecting, and hoarding behaviors among US adolescents during the coronavirus disease 2019 pandemic. JAMA Pediatr 2020 Jun 29;174(12):1184-1190. [doi: 10.1001/jamapediatrics.2020.1876] [Medline: 32597925]

42. Clements JM. Knowledge and behaviors toward COVID-19 among US residents during the early days of the pandemic: Cross-sectional online questionnaire. JMIR Public Health Surveill 2020 May 08;6(2):e19161 [FREE Full text] [doi: 10.2196/19161] [Medline: 32369759]

43. Wang P, Lu W, Ko N, Chen Y, Li D, Chang Y, et al. COVID-19-related information sources and the relationship with confidence in people coping with COVID-19: Facebook survey study in Taiwan. J Med Internet Res 2020 Jun 05;22(6):e20021 [FREE Full text] [doi: 10.2196/20021] [Medline: 32490839]

44. Franco A, Malhotra N, Simonovits G, Zigerell LJ. Developing standards for post-hoc weighting in population-based survey experiments. J Exp Pol Sci 2017 Oct 12;4(2):161-172. [doi: 10.1017/xps.2017.2]

45. Faber J, Fonseca LM. How sample size influences research outcomes. Dental Press J Orthod 2014;19(4):27-29 [FREE Full text] [doi: 10.1590/2176-9451.19.4.027-029.ebo] [Medline: 25279518]

46. Bandura A. Human agency in social cognitive theory. Am Psychol 1989 Sep;44(9):1175-1184. [doi: 10.1037/0003-066x.44.9.1175] [Medline: 2782727]

\section{Abbreviations \\ HBM: health belief model \\ OR: odds ratio \\ SCT: social cognitive theory}

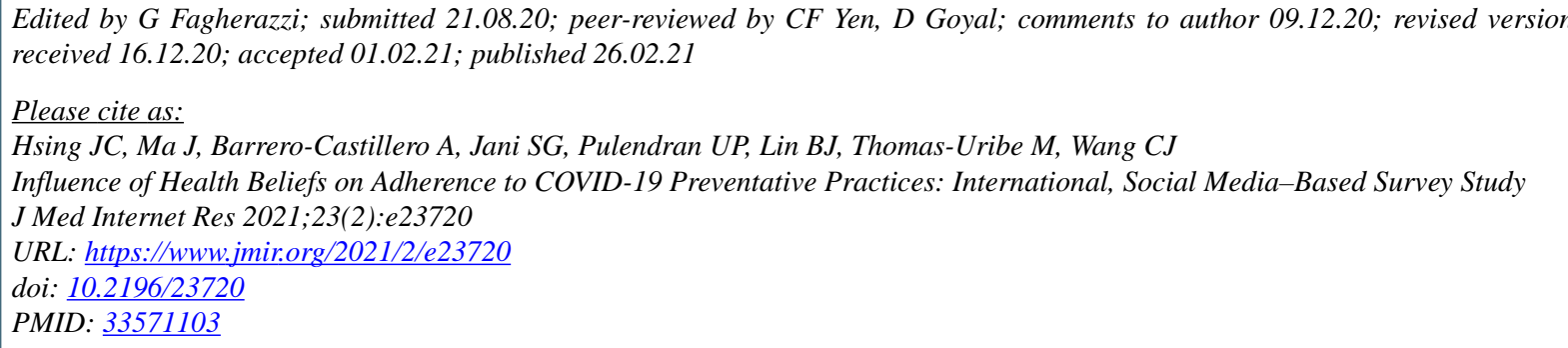

CJulianna C Hsing, Jasmin Ma, Alejandra Barrero-Castillero, Shilpa G Jani, Uma Palam Pulendran, Bea-Jane Lin, Monika Thomas-Uribe, C Jason Wang. Originally published in the Journal of Medical Internet Research (http://www.jmir.org), 26.02.2021. This is an open-access article distributed under the terms of the Creative Commons Attribution License (https://creativecommons.org/licenses/by/4.0/), which permits unrestricted use, distribution, and reproduction in any medium, provided the original work, first published in the Journal of Medical Internet Research, is properly cited. The complete bibliographic information, a link to the original publication on http://www.jmir.org/, as well as this copyright and license information must be included. 